\title{
SOME RESULTS RELATED TO BESSEL'S INEQUALITY IN INNER PRODUCT SPACES
}

\author{
Silvestru SEVER DRAGOMIR AND MOHAMED Elmursi
}

Abstract. Some inequalities related to the celebrated Bessel's inequality in inner product spaces are given. They complement the results obtained by Boas-Bellman, Bombieri, Selberg and Heilbronn in the middle of the $20^{\text {th }}$ century that have been applied for almost orthogonal series and in Number Theory.

Mathematics subject classification (2010): 46C05, $26 \mathrm{D} 15$.

Keywords and phrases: Inner product spaces, Bessel's inequality, Boas-Bellman, Bombieri, Selberg and Heilbronn inequalities.

\section{REFERENCES}

[1] R. Bellman, Almost orthogonal series, Bull. Amer. Math. Soc., 50 (1944), 517-519.

[2] R. P. BoAs, A general moment problem, Amer. J. Math., 63 (1941), 361-370.

[3] E. Bombieri, A note on the large sieve, Acta Arith., 18 (1971), 401-404.

[4] S. S. Dragomir, Discrete Inequalities of the Cauchy-Buniakowsky-Schwartz. Type, Nova Science Publishers, Inc., Hauppauge, NY, 2004. x+225 pp. ISBN: 1-59454-049-7.

[5] S. S. Dragomir, Advances in Inequalities of the Schwarz, Grüss and Bessel Type in Inner Product Spaces, Nova Science Publishers, Inc., Hauppauge, NY, 2005. viii+249 pp. ISBN: 1-59454-202-3.

[6] S. S. Dragomir, Advances in Inequalities of the Schwarz, Triangle and Heisenberg Type in Inner Product Spaces, Nova Science Publishers, Inc., New York, 2007. xii+243 pp. ISBN: 978-1-59454903-8; 1-59454-903-6.

[7] S. S. Dragomir, On the Boas-Bellman inequality in inner product spaces, Bull. Austral. Math. Soc., 69 (2004), no. 2, 217-225. Preprint RGMIA Res. Rep. Coll., 6(2003), Supplement, Article 14. [Online http://rgmia.org/papers/v6e/BBIIPS.pdf].

[8] S. S. Dragomir, On the Bombieri inequality in inner product spaces, Libertas Math., 25 (2005), 1326. Preprint RGMIA Res. Rep. Coll. 3 (2003), Art. 5 [Online http://rgmia.org/papers/v6n3/BIIPS.pdf]

[9] S. S. Dragomir, Some Bombieri type inequalities in inner product spaces, J. Indones. Math. Soc., 10 (2004), no. 2, 91-98. Preprint RGMIA Res. Rep. Coll., 6(2003), Supplement, Article 16. [Online http://rgmia.org/papers/v6e/BTIIPS.pdf] .

[10] S. S. DRAGOMIR AND B. Mond, On the Boas-Bellman generalisation of Bessel's inequality in inner product spaces, Italian J. of Pure \& Appl. Math., 3 (1998), 29-35.

[11] S. S. Dragomir, B. Mond And J. E. Pečarić, Some remarks on Bessel's inequality in inner product spaces, Studia Univ. Babeş-Bolyai, Mathematica, 37(4) (1992), 77-86.

[12] H. Heilbronn, On the averages of some arithmetical functions of two variables, Mathematica, $\mathbf{5}(1958), 1-7$.

[13] D. S. Mitrinović, J. E. PeČArić And A. M. Fink, Classical and New Inequalities in Analysis, Kluwer Academic Publishers, Dordrecht/Boston/London, 1993. 